\title{
Reintroducing Flax (Linum usitatissimum L.) to the Mediterranean Basin: The Importance of Nitrogen Fertilization
}

\author{
Ioanna Kakabouki ${ }^{1, *}{ }^{\circledR}$, Antonios Mavroeidis ${ }^{1}$, Alexandros Tataridas ${ }^{1} \oplus$, Ioannis Roussis ${ }^{1}{ }^{\oplus}$,

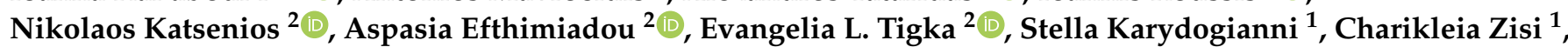 \\ Antigolena Folina ${ }^{1}$ and Dimitrios Bilalis ${ }^{1}$ D \\ 1 Laboratory of Agronomy, Department of Crop Science, Agricultural University of Athens, \\ 11855 Athens, Greece; antoniosmauroeidis@gmail.com (A.M.); a.tataridas@gmail.com (A.T.); \\ iroussis01@gmail.com (I.R.); stella.karidogianni@hotmail.com (S.K.); xarikleiazisi@gmail.com (C.Z.); \\ folinanti@gmail.com (A.F.); bilalisdimitrios@gmail.com (D.B.) \\ 2 Institute of Soil and Water Resources, Department of Soil Science of Athens, Hellenic Agricultural \\ Organization DEMETER, Sofokli Venizelou 1, 14123 Lykovrissi, Greece; nkatsenios@gmail.com (N.K.); \\ sissyefthimiadou@gmail.com (A.E.); evitiga@yahoo.gr (E.L.T.) \\ * Correspondence: i.kakabouki@gmail.com
}

check for updates

Citation: Kakabouki, I.;

Mavroeidis, A.; Tataridas, A.;

Roussis, I.; Katsenios, N.; Efthimiadou, A.; Tigka, E.L.; Karydogianni, S.; Zisi, C.;

Folina, A.; et al. Reintroducing Flax (Linum usitatissimum L.) to the Mediterranean Basin: The Importance of Nitrogen Fertilization. Plants 2021, 10, 1758. https://doi.org/10.3390/ plants10091758

Academic Editors: Anthony Quéro and Christophe Hano

Received: 19 July 2021

Accepted: 23 August 2021

Published: 24 August 2021

Publisher's Note: MDPI stays neutral with regard to jurisdictional claims in published maps and institutional affiliations.

Copyright: (c) 2021 by the authors. Licensee MDPI, Basel, Switzerland. This article is an open access article distributed under the terms and conditions of the Creative Commons Attribution (CC BY) license (https:// creativecommons.org/licenses/by/ $4.0 /)$.

\begin{abstract}
An increasing interest has been reported regarding the reintroduction of flax in the Mediterranean region. The aim of this present study was to evaluate the effects of nitrogen $(\mathrm{N})$ fertilization on the performance of flax cv. Everest, under Mediterranean climate conditions. A two-year study was carried out in 2018-2019, in Western Greece. The experiment was set-up in a randomized complete block design with four replications and six treatments of different $\mathrm{N}$ fertilization rates $(0,20,30$, 40, 50, and $60 \mathrm{~kg} \mathrm{~N} \mathrm{ha}^{-1}$ ). Measurements included plant biomass, the leaf area index (LAI), the yield, and the Growth Degree Days (GDDs) required for full seed maturity. The N uptake of flax was also evaluated utilizing the Nitrogen Harvesting (NHI) and Nitrogen Utilization Efficiency (NUtE) indices. Although the highest fertilization rate $(60 \mathrm{~N})$ increased the yield by $35.4 \%(2018)$ and $23.1 \%$ (2019), a GDDs and $\mathrm{N}$ indices assessment revealed that it noted the lowest efficiency and may lead to significant yield losses, as it significantly prolonged the crop cycle. On the contrary, even though fertilization rates of 20 and $30 \mathrm{~kg} \mathrm{~N} \mathrm{ha}^{-1}$ increased the yield only by $7 \%$ and $15 \%$ (on average), they were more efficient, and prolonged the crop cycle less (compared to $60 \mathrm{~N}$ ).
\end{abstract}

Keywords: Accumulated growing-degree days (AGDDs); flax; nitrogen fertilization; nitrogen indices; Mediterranean basin; climate change

\section{Introduction}

Flax (Linum usitatissimum L.), one of the 150 species of the Linaceae family, is a crop with great potential due to its multiple uses and its high adaptability [1,2]. Although it originates from around the Mediterranean region and Southwestern Asia [3], this adaptability to various climatic conditions spread its cultivation across the Middle East, India, Canada, and several European countries [2]. Amongst them, Canada is considered the main producer of flax [4]. Flax is cultivated either for its fiber, or its seeds and the oil produced from them [2]. In fact, flax varieties can be distinguished by either oilseed or fiber varieties [5]. The oil produced from oilseed varieties was initially used as raw material for varnish, paint, ink, and soap production [6], but, nowadays, it is included in human nutrition [7]. According to Bilalis et al. [8], flax oil is placed amongst nature's best sources of omega-3- fatty acids, while Madhusudhan [4] considered it as nature's richest source of a-linolenic acid. Furthermore, flaxseed is rich in proteins and dietary fibers, while it has been estimated that $100 \mathrm{~g}$ of flaxseed contain $450 \mathrm{kcal}$ [8]. On the contrary, fiber varieties are cultivated for industrial purposes $[9,10]$. Having been used ever since Neolithic times, flax fibers have reported a broad spectrum of applications, from human clothing to the 
creation of synthetic materials [1,11]. Flax can also be included in animal rations [12] or be used for the phytoremediation of metal-contaminated soils [10].

Throughout recent decades, an increasing interest regarding the reintroduction of flax has been reported in the Mediterranean region [13]. This increasing interest could partially be attributed to the adverse effects of climate change as the introduction of alternative crops, such as flax, to the Mediterranean countries could potentially tackle this rising problem [14]. Studies have been conducted in Italy and Spain in order to investigate the influence of sowing and harvest time, as well as irrigation, on fiber flax varieties [13,15]. However, fertilization could be the determinant factor for the successful reintroduction of flax in the Mediterranean Basin as the literature indicates that, besides tillage $[8,16]$, the factor that affects yield, seed, and fiber quality most is fertilization $[6,17,18]$, especially nitrogen $(\mathrm{N})$ fertilization [19]. $\mathrm{N}$ is known to be one of the most important nutrients for plant growth. Flax, among many other crops, is positively affected by increased $\mathrm{N}$ supply. Rahimi et al. [20] reported that the application of $\mathrm{N}$ fertilization on flax results in high yields and high-quality flaxseed. However, an $\mathrm{N}$ oversupply can delay crop maturation, as it promotes vegetative growth and potentially reduces yield. According to Franzen [21], this negative impact of excessive $\mathrm{N}$ fertilization has also been reported on flax cultivations. Many studies have aimed to define the optimum amount of applied $\mathrm{N}$ fertilization on flax, yet the results remain contradictory [22].

Nitrogen indices can facilitate the estimation of the optimal dose of nitrogen for each crop. One of the most important $\mathrm{N}$ indices is the Nitrogen Harvest Index (NHI), an index that describes the distribution of nitrogen in plant tissues [23]. In addition, Nitrogen Utilization Efficiency (NUtE) is another index that describes the amount of the groundabsorbed $\mathrm{N}$ that has been utilized by the plant for seed production [24]. These indices allow us to estimate the nitrogen losses, as well as the amount of nitrogen that has been absorbed by the crop [25] and, thus, the efficiency of the fertilization rate. However, these indices do not assess the overall performance of the crop.

A very useful index for the prediction of the crop performance is Growth Degree Days (GDDs) [26]. GDDs represent the sum of degrees over a temperature threshold in a defined period of time [27]. According to studies performed on crops such as wheat and corn, GDDs represent the amount of heat required by the crops in order to develop [28,29]. Therefore, GDDs could be perceived as a means to describe the duration of the biological cycle of the crop. Regarding the GDD requirements of flax, they have been estimated at $1150{ }^{\circ} \mathrm{C}$ for full seed maturity [30]. This roughly translates to 100-120 days after sowing (DAS) [30], or approximately five to six weeks after flowering [31]. It should be noted though that high temperatures and water supply, as well as the density of plants, can delay the maturation of crops. Therefore, environmental factors [32-34] and cultivation techniques [35] can differentiate the biological cycle length of this crop.

To our knowledge, the number of studies that have evaluated the effects of $\mathrm{N}$ fertilization on the performance of flax, utilizing GDDs and N indices, are limited. Most studies in the literature refer to the effects of nitrogen fertilization on the characteristics of the flaxseed. Thus, this study set two aims. The first one was to examine the effects of different $\mathrm{N}$ fertilization levels on the performance of this crop (yield and biological cycle), under Mediterranean conditions. The second one was to evaluate the efficiency of those fertilization levels. In order to perform these tasks, three indices were utilized: LAI, AGDDs, and NHI and NUtE.

\section{Results}

\subsection{Plant Biomass (DM)}

The fertilization-induced changes in the mean dry weight of flax are presented in Figure 1. In particular, Figure 1A depicts the biomass changes that were recorded during the first year (2018), whereas Figure 1B presents the results of the second year (2019). In 2018, the differences noted amongst the treatments during the first 30 DAS were insignificant. On the contrary, 45 DAS, significant differences were observed between the control $(0 \mathrm{~N})$ 
and the treatments $(20 \mathrm{~N}, 30 \mathrm{~N}, 40 \mathrm{~N}, 50 \mathrm{~N}$, and $60 \mathrm{~N})$, although the differences amongst the treatments were trivial. Notably, DM was increased by $35 \%$ in $60 \mathrm{~N}$, compared to the control. Although DM was significantly increased in all of the treatments 60 DAS, the differences between $50 \mathrm{~N}$ and $60 \mathrm{~N}$ were insignificant. Following the 75th DAS, all treatments reported statistically significant differences amongst them. Throughout 2018, the lowest DM values were reported in the control and the highest in $60 \mathrm{~N}$. In particular, plant biomass in $60 \mathrm{~N}$ was increased by $21.22 \%, 82.07 \%$, and $23.05 \% 30,60$, and 90 DAS, respectively, compared to the control (Figure 1A).

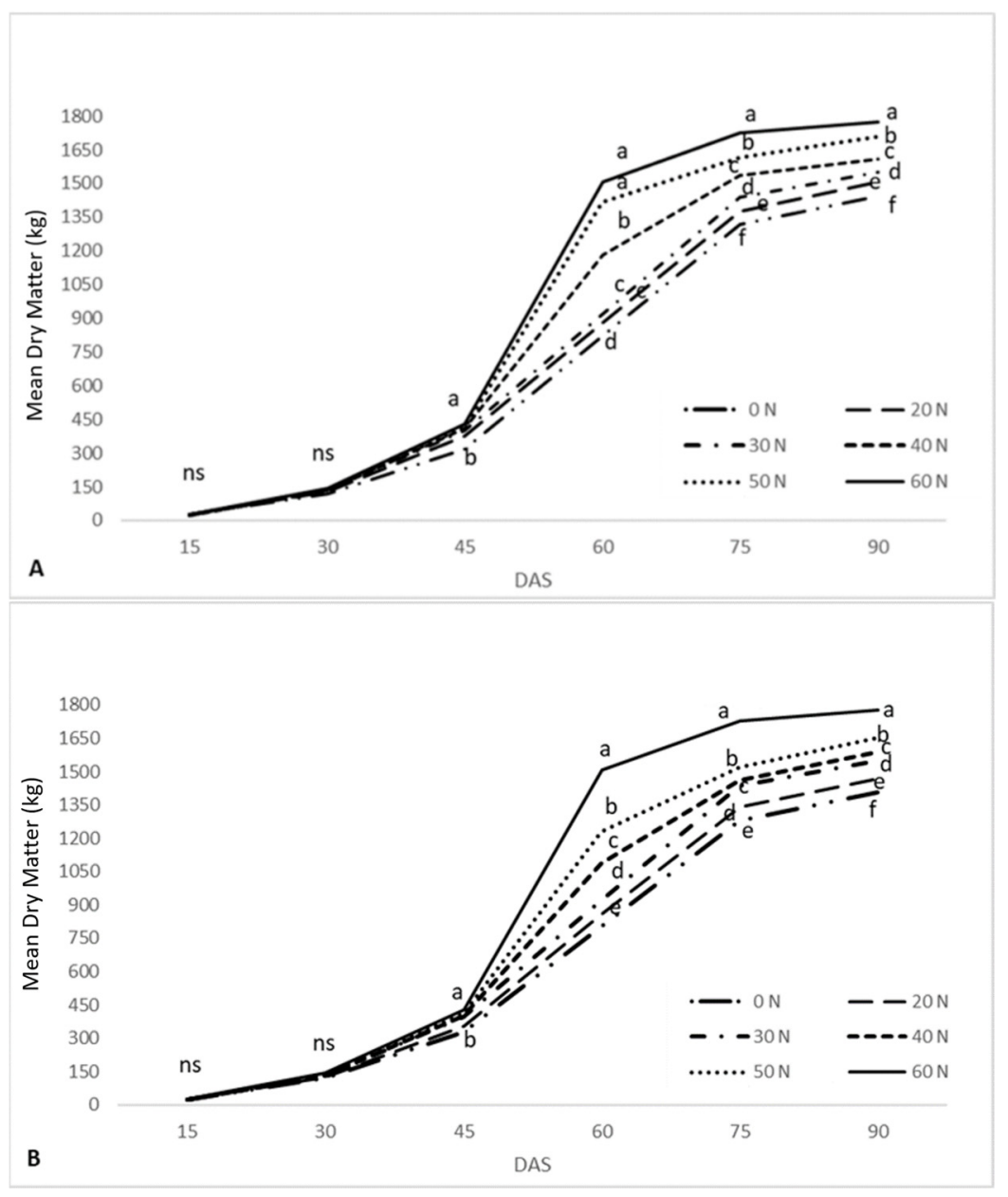

Figure 1. Changes in DM at different DAS ("ns": not statistically; different letters are significantly different at $p=0.05)$, during 2018 (A) and 2019 (B).

The results of the second year (Figure 1B) were in agreement with those of 2018. Notably, the average DM in all treatments was reduced, compared to the results of 2018. Following the 45th DAS, plant biomass reported statistically significant differences amongst the treatments. Similar to the findings of the previous year, plants in the control reported the lowest DM values throughout the duration of the experiment. The greatest DM increment (compared to the control) was once again noted in $60 \mathrm{~N}(18.1 \%, 67.44 \%$, and $21.47 \% 30$, 60 , and 90 DAS, respectively). Overall, the biomass of flax was positively correlated to $\mathrm{N}$ fertilization as higher fertilization rates resulted in significantly higher biomass accumulation.

\subsection{Leaf Area Index (LAI) and Accumulated Growth Degree Days (AGDDs)}

LAI values ranged from 1.857 to 2.372, during 2018, and from 2.007 to 2.372, during 2019 (Table 1). Although LAI values were positively correlated to $\mathrm{N}$ fertilization, 
no statistically significant differences were noted between the control and $20 \mathrm{~N}$, the $30 \mathrm{~N}$ and $40 \mathrm{~N}$, and the $50 \mathrm{~N}$ and $60 \mathrm{~N}$. The maximum LAI values were recorded in the $60 \mathrm{~N}$ during both years (2.372) and were by $27.7 \%$ (during 2018) and 18.2\% (during 2019) higher than the respective control LAI values. The AGDDs were significantly affected by $\mathrm{N}$ fertilization (Table 1). In particular, the application of 20 additional $\mathrm{kg} \mathrm{N}^{-1}$ seemed to significantly increase the AGDD requirements of flax in a season. On the contrary, the application of 10 additional $\mathrm{kg} \mathrm{N} \mathrm{ha}^{-1}$ did not affect the AGDDs, as the differences between the $20 \mathrm{~N}$ and $30 \mathrm{~N}$, the $30 \mathrm{~N}$ and $40 \mathrm{~N}$, the $40 \mathrm{~N}$ and $50 \mathrm{~N}$, and the $50 \mathrm{~N}$ and $60 \mathrm{~N}$ were not significant. The $60 \mathrm{~N}$ treatment resulted in the most notable increase in AGDDs, as they were higher by $5.3 \%$ and $8.4 \%$ (during 2018 and 2019, respectively) compared to $0 \mathrm{~N}$.

Table 1. The agronomic characteristics of flax, yield, seed N content and uptake, and the AGDDS, as affected by fertilization.

\begin{tabular}{|c|c|c|c|c|c|c|c|}
\hline Treatments & LAI & $\begin{array}{l}\text { Plant Height } \\
(\mathrm{cm})\end{array}$ & $\begin{array}{c}\text { Yield } \\
\left(\mathrm{kg} \mathrm{ha}^{-1}\right)\end{array}$ & $\begin{array}{c}1000 \\
\text { Seed Weight } \\
\text { (g) }\end{array}$ & $\begin{array}{l}\text { Seed N } \\
\text { Content } \\
\quad(\%)\end{array}$ & $\begin{array}{l}\text { Seed N Uptake } \\
\left(\mathrm{kg} \mathrm{ha}^{-1}\right)\end{array}$ & AGDDs \\
\hline \multicolumn{8}{|c|}{2018} \\
\hline $0 \mathrm{~N}$ & $1.86^{\mathrm{a}}$ & $50.75^{a}$ & $1090^{a}$ & $3.61^{\mathrm{a}}$ & $2.96^{\mathrm{a}}$ & $32.22^{\mathrm{a}}$ & $1406.4^{\mathrm{a}}$ \\
\hline $20 N$ & $1.97^{\mathrm{ab}}$ & $56.00^{b}$ & $1180^{b}$ & $3.75^{b}$ & $3.04^{b}$ & $35.85^{b}$ & $1435.3^{b}$ \\
\hline $30 \mathrm{~N}$ & $2.10^{\mathrm{c}}$ & $60.25^{c}$ & $1297^{c}$ & $3.79^{c}$ & $3.12^{b}$ & $40.48^{c}$ & $1451.8^{b c}$ \\
\hline $40 \mathrm{~N}$ & $2.15^{b c}$ & $63.50^{\mathrm{d}}$ & $1405^{d}$ & $3.90^{\mathrm{d}}$ & $3.22^{c}$ & $45.17^{d}$ & $1464.7^{\mathrm{cd}}$ \\
\hline $50 \mathrm{~N}$ & $2.27^{\mathrm{d}}$ & $66.75^{\mathrm{e}}$ & 1450 de & $3.96^{\text {de }}$ & $3.27^{\mathrm{cd}}$ & $47.45^{\mathrm{de}}$ & $1473.4^{\mathrm{de}}$ \\
\hline $60 \mathrm{~N}$ & $2.37^{\mathrm{d}}$ & $72.75^{\mathrm{f}}$ & $1476^{\mathrm{e}}$ & $4.05^{\mathrm{e}}$ & $3.34^{\mathrm{d}}$ & $49.24^{\mathrm{e}}$ & $1480.4^{\mathrm{e}}$ \\
\hline \multicolumn{8}{|c|}{2019} \\
\hline $0 \mathrm{~N}$ & $2.01^{\mathrm{a}}$ & $52.50^{\mathrm{a}}$ & $1175^{a}$ & $3.68^{a}$ & $2.99^{a}$ & $35.18^{a}$ & $1349.5^{\mathrm{a}}$ \\
\hline $20 \mathrm{~N}$ & $2.04^{\mathrm{ab}}$ & $55.50^{b}$ & $1231^{b}$ & $3.75^{b}$ & $3.09^{b}$ & $38.05^{b}$ & $1378.1^{b}$ \\
\hline $30 \mathrm{~N}$ & $2.15^{c}$ & $60.00^{c}$ & $1298^{c}$ & $3.89^{c}$ & $3.12^{b}$ & $40.52^{b c}$ & $1402.1^{b c}$ \\
\hline $40 \mathrm{~N}$ & $2.24^{b c}$ & $63.00^{\mathrm{d}}$ & $1348^{\mathrm{cd}}$ & $3.97^{d}$ & $3.18^{c}$ & $42.89^{c}$ & $1425.6^{\mathrm{cd}}$ \\
\hline $50 \mathrm{~N}$ & $2.3^{\mathrm{d}}$ & $66.50^{\mathrm{e}}$ & $1395^{\text {de }}$ & $4.05 \mathrm{de}$ & $3.24^{\mathrm{cd}}$ & $45.24^{\mathrm{cd}}$ & $1437.5^{\mathrm{de}}$ \\
\hline $60 \mathrm{~N}$ & $2.37^{\mathrm{d}}$ & $69.25^{f}$ & $1447^{\mathrm{e}}$ & $4.10^{\mathrm{e}}$ & $3.28^{\mathrm{d}}$ & $47.52^{\mathrm{d}}$ & $1462.9^{\mathrm{e}}$ \\
\hline $\mathrm{F}_{\text {Fert }}$ & $56.27^{* * *}$ & $169.26^{* * *}$ & $132.3^{* * *}$ & $57.12^{* * *}$ & $70.93^{* * *}$ & $162.58^{* * *}$ & $40.57^{* * *}$ \\
\hline $\mathrm{F}_{\text {Year }}$ & $12.357^{* * *}$ & ns & ns & $13.79^{* * *}$ & ns & ns & ns \\
\hline $\mathrm{F}_{\text {Fert }} \times$ Year & ns & ns & $6.8^{* * *}$ & ns & ns & $6.75^{* * *}$ & ns \\
\hline
\end{tabular}

Means within a column followed by the different letters are significantly different at $p=0.05$. ("ns": not statistically significant; ${ }^{* * *}$ : statistically significant for a significance level of $p<0.001)$.

\subsection{Plant Height and Yield}

Fertilization considerably affected plant height, as statistically significant differences were noted amongst all treatments, during both years. Besides the control, the plant height in the rest of the treatments was higher during 2018. Even though the plant height was significantly increased in all of the treatments (Table 1), the most notable height increment was observed in $60 \mathrm{~N}$ ( $43.3 \%$ and $31.9 \%$ compared to the $0 \mathrm{~N}$, during 2018 and 2019, respectively). The results, regarding plant height, indicate that for every 10 additional $\mathrm{kg} \mathrm{N} \mathrm{ha}^{-1}$, plant height increases by $4-9 \%$. Flaxseed yield was also positively affected by $\mathrm{N}$ fertilization, although the differences among the higher fertilization rates (between $60 \mathrm{~N}$ and $50 \mathrm{~N}$, and between $50 \mathrm{~N}$ and $40 \mathrm{~N}$ ) were insignificant. In particular, the yield in $60 \mathrm{~N}$ was only $2-4 \%$ higher than the respective one of $50 \mathrm{~N}$. The highest yield was recorded in $60 \mathrm{~N}$, where it was increased by $35.4 \%$ and $23.1 \%$ (compared to $0 \mathrm{~N}$ ), during 2018 and 2019, respectively (Table 1 ).

\subsection{Seed Weight and N Content of the Seeds}

The average weight of 1000 seeds was significantly higher during the second experimental year (Table 1). Besides $20 \mathrm{~N}$, the average weight of 1000 seeds was $1.7-2.8 \%$ higher during 2019. As with the yield response to $\mathrm{N}$ fertilization, the weight of 1000 seeds was 
positively affected by fertilization. It should be noted though that the differences between $40 \mathrm{~N}$ and $50 \mathrm{~N}$, and between $50 \mathrm{~N}$ and $60 \mathrm{~N}$ were insignificant. The best results were once again observed in $60 \mathrm{~N}$ where the 1000 seed weight was $12.3 \%$ and $11.6 \%$ (during 2018 and 2019 , respectively) higher, compared to $0 \mathrm{~N}$. In contrast to the 1000 seed weight results, the seed N content did not note significant differences between 2018 and 2019 (Table 1). The highest seed $\mathrm{N}$ content was reported in $60 \mathrm{~N}(12.9 \%$ and $9.7 \%$ higher than the respective one in 0N, during 2018 and 2019, respectively), although the differences between $50 \mathrm{~N}$ and $60 \mathrm{~N}$ were trivial.

\subsection{Above-Ground, Seed, and Total N Uptake}

The Above-ground N Uptake of the plants was significantly increased through each treatment (Table 2). In particular, the $20 \mathrm{~N}, 30 \mathrm{~N}, 40 \mathrm{~N}, 50 \mathrm{~N}$, and $60 \mathrm{~N}$ increased, on average, the respective Above-ground N Uptake of the crop by $10.5 \%, 20.5 \%, 33.3 \%, 45.1 \%$, and $56.7 \%$, respectively, compared to the control (0N). Similarly, the Seed N Uptake increased with fertilization rates, although the differences amongst the higher fertilization rates $(40 \mathrm{~N}$ and $50 \mathrm{~N}$, and $50 \mathrm{~N}$ and $60 \mathrm{~N}$ ) were insignificant (Table 1). During 2018, 40N, $50 \mathrm{~N}$, and $60 \mathrm{~N}$ increased Seed N Uptake (compared to $0 \mathrm{~N}$ ) by $40.2 \%, 47.3 \%$, and $52.8 \%$, respectively, while during 2019, the same treatments increased the Seed N Uptake by $21.9 \%, 28.6 \%$, and $35.1 \%$. The Total N Uptake was also positively affected by fertilization. This positive correlation between Total N Uptake and fertilization was anticipated due to the fertilization-induced increment in the Above-ground and Seed Uptake. The highest Total N Uptake was recorded in $60 \mathrm{~N}$ during both years $(53.6 \%$ and $37.9 \%$ higher compared to $0 \mathrm{~N}$, during 2018 and 2019 , respectively), followed by $50 \mathrm{~N}(47.2 \%$ and $30.7 \%), 40 \mathrm{~N}(39.1 \%$ and $23.6 \%), 30 \mathrm{~N}(24.7 \%$ and $16 \%)$, and $20 \mathrm{~N}(11.1 \%$ and $8.5 \%)$ (Table 2).

Table 2. The $\mathrm{N}$ content of the above-ground plant tissues, the Above-ground and Total N Uptake, and the $\mathrm{N}$ indices, as affected by the fertilization.

\begin{tabular}{|c|c|c|c|c|c|}
\hline Treatments & $\begin{array}{c}\text { N Content of the } \\
\text { Above-Ground Tissues } \\
(\%)\end{array}$ & $\begin{array}{c}\text { Above-Ground N } \\
\text { Uptake } \\
\left(\mathrm{kg} \mathrm{ha}^{-1}\right)\end{array}$ & $\begin{array}{l}\text { Total N Uptake } \\
\quad\left(\mathrm{kg} \mathrm{ha}^{-1}\right)\end{array}$ & NHI & NUtE \\
\hline \multicolumn{6}{|c|}{2018} \\
\hline $0 \mathrm{~N}$ & $0.40^{\mathrm{a}}$ & $5.70^{\mathrm{a}}$ & $37.92^{\mathrm{a}}$ & $0.849^{\mathrm{ns}}$ & $28.752^{a}$ \\
\hline $20 \mathrm{~N}$ & $0.42^{b}$ & $6.29^{b}$ & $42.13^{b}$ & $0.851^{\mathrm{ns}}$ & $28.015^{b}$ \\
\hline $30 N$ & $0.44^{\mathrm{b}}$ & $6.82^{c}$ & $47.30^{\mathrm{c}}$ & $0.856^{\mathrm{ns}}$ & $27.434^{b}$ \\
\hline $40 \mathrm{~N}$ & $0.47^{\mathrm{c}}$ & $7.57^{\mathrm{d}}$ & $52.73^{\mathrm{d}}$ & $0.857^{\mathrm{ns}}$ & $26.643^{c}$ \\
\hline $50 \mathrm{~N}$ & $0.49^{c d}$ & $8.37^{\mathrm{e}}$ & $55.82^{\mathrm{e}}$ & $0.850^{\mathrm{ns}}$ & $25.979 \mathrm{~d}$ \\
\hline $60 N$ & $0.51^{\mathrm{d}}$ & $9.01^{\mathrm{f}}$ & $58.25^{\mathrm{e}}$ & $0.845^{\mathrm{ns}}$ & $25.352^{\mathrm{e}}$ \\
\hline \multicolumn{6}{|c|}{2019} \\
\hline $0 \mathrm{~N}$ & $0.40^{\mathrm{a}}$ & $5.67^{\mathrm{a}}$ & $40.85^{a}$ & $0.863^{\mathrm{ns}}$ & $28.845^{\mathrm{a}}$ \\
\hline $20 \mathrm{~N}$ & $0.43^{b}$ & $6.28^{b}$ & $44.33^{\mathrm{b}}$ & $0.861^{\mathrm{ns}}$ & $27.869^{b}$ \\
\hline $30 \mathrm{~N}$ & $0.45^{b}$ & $6.88^{c}$ & $47.39^{c}$ & $0.856^{\mathrm{ns}}$ & $27.422^{b}$ \\
\hline $40 N$ & $0.48^{c}$ & $7.59^{\mathrm{d}}$ & $50.48^{d}$ & $0.852^{\mathrm{ns}}$ & $26.780^{\mathrm{c}}$ \\
\hline $50 \mathrm{~N}$ & $0.49^{\mathrm{cd}}$ & $8.14^{\mathrm{e}}$ & $53.38^{\mathrm{e}}$ & $0.848^{\mathrm{ns}}$ & $26.156^{d}$ \\
\hline $60 N$ & $0.52^{d}$ & $8.81^{\mathrm{f}}$ & $56.33^{f}$ & $0.845^{\mathrm{ns}}$ & $25.756^{e}$ \\
\hline $\mathrm{F}_{\text {Fert }}$ & $38.496^{* * *}$ & $96.627^{* * *}$ & $218.425^{* * *}$ & $2.62^{*}$ & $125.632^{* * *}$ \\
\hline $\mathrm{F}_{\text {Year }}$ & ns & ns & ns & ns & ns \\
\hline $\mathrm{F}_{\text {Fert }} \times$ Year & ns & ns & $6.361^{* * *}$ & ns & ns \\
\hline
\end{tabular}

Means within a column followed by the different letters are significantly different at $p=0.05$. ("ns": not statistically significant; *: statistically significant for a significance level of $p<0.05$; ***: statistically significant for a significance level of $p<0.001$ ).

\subsection{Nitrogen Harvest Index (NHI) and Nitrogen Utilization Efficiency (NUtE)}

The values of the nitrogen harvest index (NHI) ranged from 0.845 to 0.857 during the first year, and from 0.845 to 0.863 during the second year. The highest NHI value was recorded in the 40N during 2018 (0.857), and in the control (0N) during 2019 (0.863). 
The lowest NHI values were recorded in $60 \mathrm{~N}$ during both years (0.845). It should be noted though that the differences between the treatments were found statistically insignificant during both years (Table 2). On the contrary, the NUtE values significantly decreased with the fertilization rates. Therefore, the highest NUtE values were reported in the control during both years (Table 2) and the lowest in the $60 \mathrm{~N}$ (reduced by $11.8 \%$ and $10.7 \%$ compared to $0 \mathrm{~N}$, during 2018 and 2019, respectively). The lower fertilization rates (20N and $30 \mathrm{~N}$ ) did not report any statistically significant differences amongst them.

\section{Discussion}

The results of our study initially indicated a positive correlation between AGDDs, the agronomic characteristics of flax, and the weight of 1000 seeds (Table 3). Similar findings have been reported by Mirshekari et al. [36], though in their research, the positive correlation between GDDs and seed traits was attributed to the difference in sowing days. According to Mirshekari et al. [36], early or late sowing dates affect day length, photoperiod, and other factors that may or may not cause abiotic stress on the plants and, therefore, alter the growing cycle of flax and potentially increase or decrease yield. In this present study, AGDDs were utilized as a mere indicator of the effects of $\mathrm{N}$ fertilization on the length of the growing cycle of the crop. Indeed, our results reveal that under the same edaphoclimatic conditions, the application of $\mathrm{N}$ fertilization increases the AGDDs (by 74 and 113 GDDs on 2018 and 2019, respectively) required for full seed maturity; thus, it is safe to assume that providing additional $\mathrm{N}$ to flax prolongs the vegetive phase of the plant and delays seed maturity, as Franzen [21] proposed. Therefore, the positive correlation between AGDDs, and plant height and biomass (Table 3) can be interpretated as the result of a longer vegetative phase that led to larger stems, more branches, and enhanced canopy.

Table 3. Correlation matrix among AGDDs, seed traits, yield, agronomic features of flax, and N indicies.

\begin{tabular}{ccccccccc}
\hline & AGDDs & N\% Seed & N\% Upper & N Seed & N Upper & N Total & NHI & NUtE \\
\hline AGDDs & - & $0.668^{* * * *}$ & $0.656^{* * *}$ & $0.702^{* * *}$ & $0.723^{* * *}$ & $0.714^{* * *}$ & $-0.410^{* *}$ & $-0.701^{* * *}$ \\
Plant Height & $0.745^{* * *}$ & $0.946^{* * *}$ & $0.914^{* * *}$ & $0.962^{* * *}$ & $0.961^{* * *}$ & $0.971^{* * *}$ & $-0.427^{* *}$ & $-0.964^{* * *}$ \\
DM & $0.769^{* * *}$ & $0.904^{* * *}$ & $0.873^{* * *}$ & $0.918^{* * *}$ & $0.961^{* * *}$ & $0.934^{* * *}$ & $-0.535^{* *}$ & $-0.946^{* * *}$ \\
Yield & $0.695^{* * *}$ & $0.942^{* * *}$ & $0.895^{* * *}$ & $0.994^{* * *}$ & $0.924^{* * *}$ & $0.992^{* * *}$ & $-0.270^{\mathrm{ns}}$ & $-0.929^{* * *}$ \\
1000 seed weight & $0.622^{* *}$ & $0.807^{* * *}$ & $0.895^{* * *}$ & $0.860^{* * *}$ & $0.903^{* * *}$ & $0.876^{* *}$ & $-0.513^{* *}$ & $-0.856^{* * *}$ \\
\hline
\end{tabular}

Significance levels: ${ }^{* *} p<0.01 ;{ }^{* * *} p<0.001 ;$ ns, not significant $(p>0.05)$.

Regarding the effects of $\mathrm{N}$ fertilization on the performance of flax, as presented in Table 1 and Figure 1, the application of $\mathrm{N}$ fertilization clearly affected the agronomic characteristics (height and the biomass) of the plants. This positive response of height to $\mathrm{N}$ fertilization has been reported before. In particular, Ali et al. [37] observed that the application of $75 \mathrm{~kg} \mathrm{ha}^{-1}$ of $\mathrm{N}$ fertilization increased the height of the plants by approximately $15.6 \%$. In contrast to the findings of Ali et al. [37], in our study, the height of plants treated with $30 \mathrm{~kg} \mathrm{~N}^{-1}(30 \mathrm{~N})$ was increased by $16.45 \%$ (average height increase of both years), indicating that lower levels of $\mathrm{N}$ fertilization led to greater increases in the height of the plants. This dissimilarity could be attributed to different initial levels of soil N. This hypothesis could also explain the contradictory findings of Kariuki et al. [38], as their results found no significant interaction between fertilization and plant height. Other potential explanations include $\mathrm{N}$ leaching and genetic factors, as the varieties of flax used on each occasion were different.

The augmentation of the biomass (DM) of the plants due to the application of $\mathrm{N}$ fertilization has also been reported by other researchers. Soethe et al. [39] noted a positive linear increase while examining the interaction of $\mathrm{N}$ fertilization and the biomass of flax plants. In our study, during both experimental years, the dry weight of the plants was significantly affected by fertilization, particularly on treatments with higher fertilization rates (Figure 1). This positive interaction between fertilization and biomass could initially be attributed to the aforementioned prolongation of the vegetive phase that results in the formation 
of more above-ground plant organs (e.g., leaves and branches) compared to untreated plants. Furthermore, studies have suggested that $\mathrm{N}$ affects the photosynthetic processes of the plants [40] due to its importance for the Rubisco carboxylating enzyme [41-43] and chlorophyll a and b [44,45]. In fact, according to Yu et al. [46] and Maleva et al. [47], higher contents of chlorophyll $\mathrm{a}$ and chlorophyll $\mathrm{b}$ ensure higher plant biomass. The increased LAI values recorded in the present study (Table 1) also indicate increased fertilizer-induced photosynthetic activity. Finally, it should be noted that, as presented in Figure 1, a significant increment in flax dry weight was observed following the $45^{\text {th }}$ DAS when the canopy of the plants was well-developed [30] and photosynthetic activity was arguably more intense.

The yield was also significantly increased as fertilization levels were increased. Studies in the literature also support our results as $\mathrm{N}$ fertilizations reportedly increase flaxseed yields [21,38,48]. According to Kariuki et al. [38], $\mathrm{N}$ fertilization increases vegetative growth, which results in a greater number of capsules per plant and, therefore, each plant produces more seeds. In our study, the application of $130 \mathrm{~kg}$ of urea per ha $(60 \mathrm{~N})$ resulted in the greatest increment in seed production as it increased flaxseed yield by $35.4 \%$ and $23.1 \%$ in 2018 and 2019, respectively. Notably, these results contradict the findings of Franzen [21] as he stated that fertilization rates greater than $56 \mathrm{~kg} \mathrm{~N}^{-1}$ (for no-till production) tend to reduce yields on flax due to the greater susceptibility to diseases and lodging. Such phenomena were not observed at significant rates throughout our study. In fact, a wide range of fertilization rates (20-120 kg N per ha) have been proposed on flax cultivations throughout the world, and in certain instances, they far exceed Franzens' proposition [19,49-51] These contradictions are sensible as soil properties and soil fertility vastly differentiate on each occasion and, thus, these factors should always be considered [21]. Consequently, the amount of additional $\mathrm{N}$ provided through fertilization should perhaps be evaluated alongside the efficiency of the fertilization.

In order to perform this evaluation, two nitrogen indices were utilized in our study: $\mathrm{NHI}$ and NUtE. For the estimation of NUtE, the Above-ground N uptake (ANU), Seed N uptake (SNU), and Total N uptake (TNU) had to be measured first. ANU, SNU, and TNU were found positively correlated with $\mathrm{N}$ fertilization as their values increased with fertilization rates (Table 2). The observations regarding ANU and TNU were anticipated as the biomass and the $\mathrm{N}$ content of the plants were affected by the fertilization, as mentioned above. The increased values of SNU, however, and especially the increment in N\% of the seeds, are in disagreement with the literature. According to Rahimi et al. [20], as the yield increases, the $\mathrm{N}$ content of the seeds tends to decrease, as these factors are negatively correlated. Moreover, $\mathrm{N}$ fertilization is believed to impede the seed-filling of various crops [52]. However, studies have indicated that the $\mathrm{N}$ content of flaxseed is negatively correlated with their oil content $[53,54]$. This equilibrium between $\mathrm{N}$ and oil content could perhaps justify our results as studies in the literature have suggested that high $\mathrm{N}$ fertilization rates negatively affect the oil content of the seed [22,55,56]. This phenomenon is called the "dilution effect" and is the result of the oil-diluting, protein and starch accumulation in the seed due to the $\mathrm{N}$-induced promotion of the vegetative growth that delays grain filling and grain maturity [57]. It should be noted though that the oil content of the seeds was not measured in the present study.

The values of NUtE, in contrast to those of ANU, SNU, and TNU, were negatively correlated with $\mathrm{N}$ fertilization rates (Table 2). Furthermore, NHI was not significantly affected by fertilization (Table 2). Both of these indices were also found negatively correlated with the agronomic characteristics of the plants and the weight of 1000 seeds (Table 3). Based on these observations, it is safe to assume that although $\mathrm{N}$ fertilization improved the overall performance of flax, higher rates of fertilization were less efficient, probably due to $\mathrm{N}$ losses. These losses were potentially caused by nitrate leaching [58] or ammonia volatilization [59]. $\mathrm{N}$ losses are a well-known problem of modern-age agriculture with severe environmental imprints [60-62]. The economic and ecological aspects of fertilization need to be addressed as our results suggest a noteworthy inefficiency of urease fertilization. Although the application of $130 \mathrm{~kg} \mathrm{ha}^{-1}(60 \mathrm{~N})$ of urease fertilizer resulted in a sufficient 
increment in yield, perhaps the use of slow-release fertilizers should be considered on flax crops. Experiments conducted by Kakabouki et al. [63] regarding the application of slow-release fertilizers with urease and nitrification inhibitors on flax were encouraging. Nevertheless, further research should be conducted regarding this aspect.

Overall, despite the positive response in yield, higher urea fertilization rates seem inadequate. Besides the aforementioned reduced efficacy of these rates, the prolongation of the biological cycle of the crop might also result in reduced yields and inadequate seed quality in the near future. As the adverse effects of climate change are evident in the Mediterranean Basin, the mean temperature is expected to rise even more in the future [64,65]. Despite the great acclimatization potential of flax, temperatures over $30^{\circ} \mathrm{C}$ and precipitations over $700 \mathrm{~mm}$ per year do not favor its growth [12]. Figure 1 depicts that during the summer months, mean temperatures rise close to $30^{\circ} \mathrm{C}$. According to Kraft et al. [66], exposing flax to temperatures above $30^{\circ} \mathrm{C}$ for more than 5 days during the period from flowering to complete seed maturity results in reduced seed production. Similarly, Gusta et al. [67] stated that in the absence of drought stress, exposure to temperatures over $30^{\circ} \mathrm{C}$ for 7 days reduces seed production by $30 \%$. Therefore, as high $\mathrm{N}$ fertilization levels delay harvest, they could potentially lead to yield losses in the near future due to the high temperatures of the summer months in the Mediterranean Basin. Early sowing could be a possible solution to this problem; nevertheless, further research should be conducted on the effects of sowing dates and fertilization rates on the yield of flax under the Mediterranean climate conditions.

\section{Materials and Methods}

\subsection{Experimental Design}

The experiment took place in 2018, in Agrinio, Western Greece $\left(38^{\circ} 33^{\prime} \mathrm{N}, 21^{\circ} 24^{\prime} \mathrm{E}\right)$, and was then repeated for a second year (2019) in the same field. The soil properties of the field are presented in Table 4. The measurements were conducted de novo and in the Laboratory of Agronomy at the Agricultural University of Athens $\left(37^{\circ} 59^{\prime} 01.1^{\prime \prime} \mathrm{N}\right.$ $23^{\circ} 42^{\prime} 12.0^{\prime \prime}$ E). The forecrop was maize. Each year, three weeks prior to the sowing, the stale seed bed technique was applied on the field. During this period, once a week, a light irrigation was performed in order to stimulate weed emergence. Weeds were then removed by hand. Similarly, throughout the duration of the experiment, the field was weekly inspected, and weeds were removed by hand. Hand weeding was favored over chemical management as several herbicides (pendimethalin, MCPA, Dicamba) that are widely used in Greece (both pre- and post-emergent) have been reported to injure flax [68-70]. For the establishment of the experimental field, 300 seeds of the oil variety Everest (Linum usitatissimum L. cv. Everest) per $\mathrm{m}^{2}$ were sown by hand at a depth of $1 \mathrm{~cm}$ and with a $20 \mathrm{~cm}$ row spacing. On the first year, the sowing was performed on 22 March (2018), and on the second, on 26 March (2019). The experimental area was, in total, $480 \mathrm{~m}^{2}$. The experiment was set-up in a Complete Randomized Block Design (CRBD) with four replications and six different treatments (0N/Control, 20N, 30N, 40N, $50 \mathrm{~N}$, and $60 \mathrm{~N}$ ); therefore, each plot was $20 \mathrm{~m}^{2}$. On each treatment, a different rate of fertilization was applied (Table 5). The fertilizer used was NUTRIPLUS (urea based, N-P-K: 46-0-0), by Phytothreptiki S.A. (Ano Liosia, West Attica, Greece). According to the literature, when flax is cultivated under a no-tillage system, fertilizers should be broadcasted prior to the sowing [71]; thus, each year, 3 days prior to the sowing, the fertilizer was broadcasted, and the field was irrigated. Following the crop establishment, the field was irrigated twice each year (once during flowering and once during early pod filling) through a sprinkler irrigation system that provided a total of $250 \mathrm{~mm}$ of water per irrigation. The meteorological data (mean temperature, precipitations) recorded during these two years are presented below (Figure 2) and were derived from the weather station in Agrinio of the National Observatory of Athens. The experiment ended on June 30 in 2018, and on 4 July in 2019. 
Table 4. Soil properties of the experimental field.

\begin{tabular}{cc}
\hline Soil Type & Clay Loam \\
\hline Clay & $29.8 \%$ \\
Silt & $34.3 \%$ \\
Sand & $35.9 \%$ \\
pH & 7.22 \\
Organic matter & $2.25 \%$ \\
CaCO $_{3}$ & $14 \%$ \\
Total Mineral Nitrogen & $0.149 \%$ \\
Phosphorus-P Olsen & $170 \mathrm{mg} \mathrm{kg}^{-1}$ soil \\
Potassium & $625 \mathrm{mg} \mathrm{kg}^{-1}$ soil \\
\hline
\end{tabular}

Table 5. Treatments and amount of applied $\mathrm{N}$ fertilization.

\begin{tabular}{ccc}
\hline Treatment & Applied Fertilizer (kg ha $\left.{ }^{-\mathbf{1}}\right)$ & Fertilization Rate (kg N ha $^{\mathbf{- 1}}$ ) \\
\hline 0N (Control) & - & - \\
20N & 43.5 & 20 \\
30N & 65 & 30 \\
$40 \mathrm{~N}$ & 87 & 40 \\
$50 \mathrm{~N}$ & 109 & 50 \\
$60 \mathrm{~N}$ & 130.5 & 60 \\
\hline
\end{tabular}

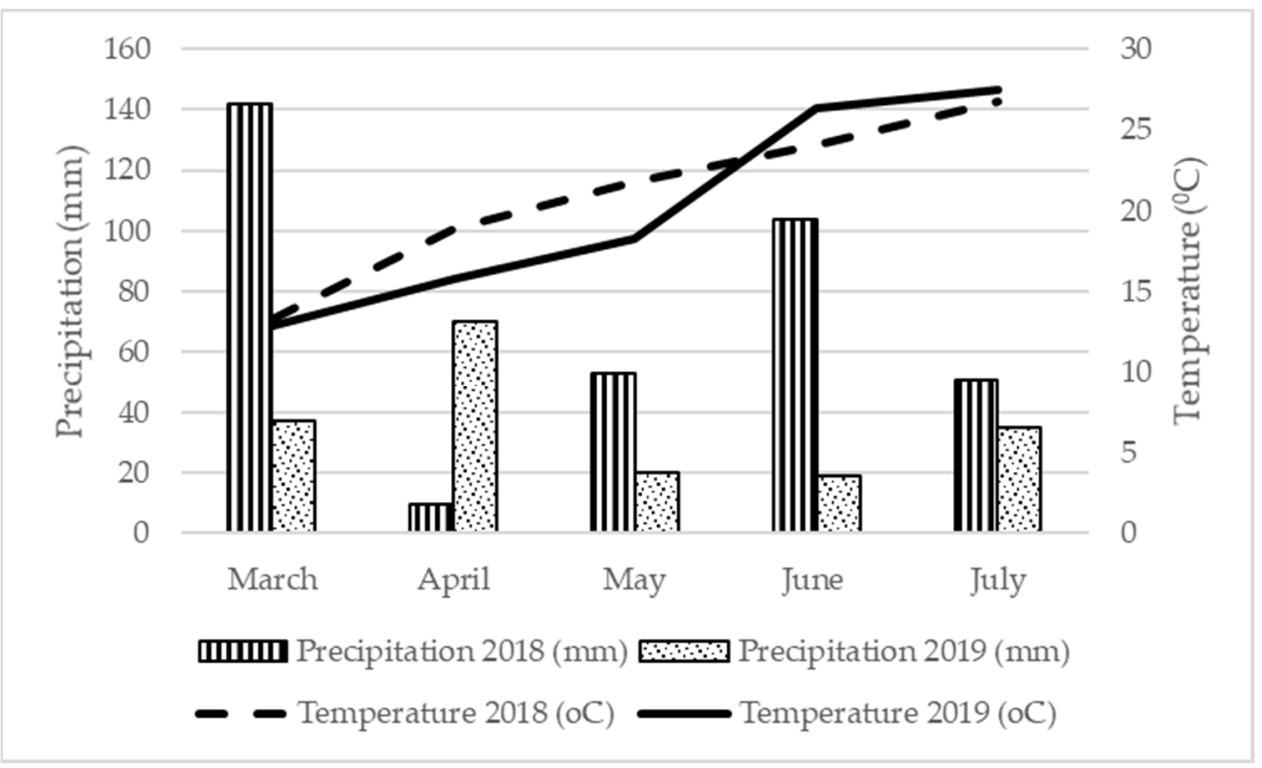

Figure 2. Mean monthly temperature $\left({ }^{\circ} \mathrm{C}\right)$ and precipitation $(\mathrm{mm})$ recorded on the experimental fields throughout the duration of the experiments (March-July, 2018-2019).

\subsection{Measurements}

The biomass of the plants (DM) was measured at 15, 30, 45, 60, 75, and 90 DAS and the height of the plants was measured 90 DAS. For the estimation of the plant biomass, three $0.25 \mathrm{~m}^{2}$ quadrats were placed randomly in each plot. The plants within these plots were clipped at ground level and placed in an oven at $80{ }^{\circ} \mathrm{C}$ for $72 \mathrm{~h}$. The Leaf Area Index (LAI) was measured using an automatic leaf area meter (Delta-T Devices Ltd., Cambridge, UK) 60 DAS, at the fast vegetation-growth stage [30]. The yield $\left(\mathrm{kg} \mathrm{ha}^{-1}\right)$ and the weight of 1000 seeds ( $\mathrm{g}$ ) were measured on the day of the harvest. Each plot was harvested at full seed maturity (seed moisture was at 13\%) and the harvest was conducted by hand.

The $\mathrm{N}$ content of the above-ground plant tissues and the seeds was measured by applying the Kjeldahl method [72], using a Buchi 316 device (BÜCHI Labortechnik AG, 
Flawil, Switzerland). Following the harvest, 5 dried plant samples and $10 \mathrm{~g}$ of seed were collected from each plot, and then grounded to a fine powder in order to estimate their $\mathrm{N}$ content. The $\mathrm{N}$ uptake of the above-ground plant tissues (Above-ground $\mathrm{N}$ uptake) and the seeds (Seed N Uptake) was estimated according to Equations (1)-(3) (Table 6). For the assessment of the $\mathrm{N}$ content and $\mathrm{N}$ uptake, two nitrogen indices were utilized, the Nitrogen Harvest Index and the Nitrogen Utilization Efficiency (Table 6). The Nitrogen Harvest Index (NHI) is defined as a ratio of the seed $\mathrm{N}$ uptake to the total $\mathrm{N}$ uptake of the plant (4) [23]. Nitrogen Utilization Efficiency (NUtE) is defined as the ratio of the yield to the total N uptake (5) [24]. Finally, the Accumulated Growth Degree Days (GDDs) were also calculated, from sowing to harvest day, according to Equation (6) (Table 6).

Table 6. The equations used in the present study and their corresponding number.

\begin{tabular}{|c|c|c|}
\hline Equation & Equation Number & Reference \\
\hline Above - ground $N$ uptake $=\frac{D M\left(\mathrm{~kg} \mathrm{ha}^{-1}\right) * \text { Above }- \text { ground tissues } N \text { content }(\%)}{100}$ & $(1)$ & [25] \\
\hline Seed $N$ uptake $=\frac{\text { Seed yield } * \text { seed } N \text { content }(\%)}{100}$ & (2) & [25] \\
\hline Total $N$ uptake $=$ Above-ground $N$ uptake + Seed $N$ uptake $\left(\mathrm{kg} \mathrm{ha}^{-1}\right)$ & (3) & [25] \\
\hline NHI $=\frac{\text { Seed N uptake }}{\text { Total N uptake }}$ & $(4)$ & {$[25]$} \\
\hline$N U t E=\frac{\text { Seed Yield }}{\text { Total N uptake }}$ & (5) & {$[25]$} \\
\hline$A G D D_{n}=\sum_{i=1}^{n}\left(\frac{T_{\max }+T_{\min }}{2}\right)-T_{\text {base }} 1$ & (6) & {$[30]$} \\
\hline
\end{tabular}

${ }^{1} \mathrm{Tmax}$ is the highest daily temperature value. Tmin is the lowest daily temperature value. Tbase for flax is $5{ }^{\circ} \mathrm{C}[30]$.

\subsection{Statistical Analysis}

Analysis of variance was carried out using the Statistica (Stat Soft, 2011) logistic package. Significant differences between treatments were compared using Tukey's HSD (honestly significant difference) test at the $5 \%$ level of probability $(p<0.05)$.

\section{Conclusions}

Flax responds positively to urea-based $\mathrm{N}$ fertilization. Our results suggest that high $\mathrm{N}$ fertilization rates can potentially increase flaxseed yield even by $35 \%$. These fertilization rates, nevertheless, were found to be inefficient as a significant portion of the fertilizer was not assimilated by the crop (it was probably volatized or leached). Concurrently, the high fertilization rates prolong the crop cycle. This should be taken into account in order to successfully reintroduce flax in the Mediterranean Basin, as flaxseed is susceptible to the high temperatures of the summer months. Even though further research should be conducted, the results of this present study indicate that low fertilization rates (e.g., 20-30 $\mathrm{kg} \mathrm{N} \mathrm{ha}^{-1}$ ) should be considered when cultivating flax in the Mediterranean region, as the adverse effects of climate change may pose a threat, in the near future, to flaxseed production.

Author Contributions: Conceptualization, I.K. and D.B.; methodology, N.K., A.E., E.L.T., I.R., S.K., C.Z., A.F. and D.B.; validation, D.B. and A.F.; formal analysis, S.K., C.Z. and I.R.; investigation, S.K., C.Z., I.R., A.E., N.K. and D.B.; resources, A.F.; writing-original draft preparation, I.K., A.M., A.T. and D.B.; writing-review and editing, I.K., A.M., A.T. and D.B; supervision, I.K. and D.B. All authors have read and agreed to the published version of the manuscript.

Funding: This research received no external funding.

Institutional Review Board Statement: Not applicable.

Informed Consent Statement: Not applicable.

Data Availability Statement: All data generated or analyzed during this study are included in this published article. Further inquiries can be addressed to the corresponding author.

Conflicts of Interest: The authors declare no conflict of interest. 


\begin{abstract}
Abbreviations
N, Nitrogen; AGDDs, Accumulated Growth Degree Days; DAS, Days After Sowing; NHI, Nitrogen Harvest Index; NUtE, Nitrogen Utilization Efficiency; DM, Dry Matter; LAI, Leaf Area Index; ANU, Above-ground Nitrogen Uptake; SNU, Seed Nitrogen Uptake; TNU, Total Nitrogen Uptake.
\end{abstract}

\title{
References
}

1. Jhala, A.J.; Hall, L.M. Flax (Linum usitatissimum L.): Current uses and future applications. AJBAS 2010, 4, 4304-4312.

2. Kiryluk, A.; Kostecka, J. Pro-environmental and health-promoting grounds for restitution of flax (Linum usitatissimum L.) cultivation. J. Ecol. Eng. 2020, 21, 99-107. [CrossRef]

3. Bilalis, D.; Roussis, I.; Cheimona, N.; Kakabouki, I.; Travlos, I. Organic agriculture and innovative feed crops. In Agricultural Research Updates; Gorawala, P., Mandhatri, S., Eds.; Nova Science Publishers Inc.: New York, NY, USA, 2018; Volume 23, pp. 70-72.

4. Madhusudhan, B. Potential benefits of flaxseed in health and disease-A perspective. Agric. Conspec. Sci. 2009, 74, 67-72.

5. Millam, S.; Obert, B.; Pret'ová, A. Plant cell and biotechnology studies in Linum usitatissimum-A review. PCTOC 2005, 82, 93-103. [CrossRef]

6. Laza, A.; Pop, G. The influence of fertilization and seeding density on flax oil production quality. Res. J. Agric. Sci. 2012, 44, 96-102.

7. Zhang, Z.S.; Wang, L.J.; Li, D.; Li, S.J.; Özkan, N. Characteristics of flaxseed oil from two different flax plants. Int. J. Food Prop. 2011, 14, 1286-1296. [CrossRef]

8. Bilalis, D.; Karkanis, A.; Papastylianou, P.; Patsiali, S.; Athanasopoulou, M.; Barla, G.; Kakabouki, I. Response of organic linseed (Linum usitatissimum L.) to the combination of tillage systems, (minimum, conventional and no-tillage) and fertilization practices: Seed and oil yield production. Aust. J. Crop Sci. 2010, 4, 700-705.

9. Saleem, M.H.; Ali, S.; Hussain, S.; Kamran, M.; Chattha, M.S.; Ahmad, S.; Aqeel, M.; Rizwan, M.; Aljarba, N.H.; Alkahtani, S.; et al. Flax (Linum usitatissimum L.): A potential candidate for phytoremediation? Biological and economical points of view. Plants 2020, 9, 496. [CrossRef] [PubMed]

10. Pickering, K.L.; Efendy, M.G.A.; Le, T.M. A review of recent developments in natural fibre composites and their mechanical performance. Compos. Part A Appl. Sci. Manuf. 2016, 83, 98-112. [CrossRef]

11. Sammour, R.H. Proteins of linseed (Linum usitatissimum L.), extraction and characterization by electrophoresis. Bot. Bull. Acad. Sin. 1999, 40, 121-126.

12. Sultana, C. Growing and harvesting of flax. In The Biology and Processing of Flax; Sharma, H., Van sumere, C., Eds.; M Publications: Belfast, UK, 1992; pp. 83-109.

13. Rossini, F.; Casa, R. Influence of sowing and harvest time on fibre flax (Linum usitatissimum L.) in the Mediterranean environment. J. Agron. Crop Sci. 2003, 189, 191-196. [CrossRef]

14. Bilalis, D.; Roussis, I.; Fuentes, F.; Kakabouki, I.; Travlos, I. Organic agriculture and innovative crops under Mediterranean conditions. Not. Bot. Horti Agrobot. Cluj-Napoca 2017, 45, 323-331. [CrossRef]

15. Lloveras, J.; Santiveri, F.; Gorchs, G. Hemp and flax biomass and fiber production and linseed yield in irrigated Mediterranean conditions. J. Ind. Hemp 2006, 11, 3-15. [CrossRef]

16. Bilalis, D.; Karkanis, A.; Pantelia, A.; Patsiali, S.; Konstantas, A.; Efthimiadou, A. Weed populations are affected by tillage systems and fertilization practices in organic flax (Linum usitatissimum L.) crop. Aust. J. Crop Sci. 2012, 6, 157-163.

17. Liu, F.; Li, F.; Du, G.; Xiao, F. Balanced fertilization improves fiber yield and quality of winter flax (Linum usitatissimum L.). Am. J. Plant Sci. 2013, 4, 291-296. [CrossRef]

18. Jogić, V.; Džafić, S.; Nikitović, J. Effects of fertilization on the fatty acid content of oil flax. Int. J. Adv. Agric. Sci. Technol. 2018, 5, 21-27.

19. Hocking, P.J.; Randall, P.J.; Pinkerton, A. Mineral nutrition of linseed and fiber flax. Adv. Agron. 1987, 41, 221-296. [CrossRef]

20. Rahimi, M.M.; Zarei, M.A.; Arminian, A. Selection criteria of flax (Linum usitatissimum L.) for seed yield, yield components and biochemical compositions under various planting dates and nitrogen. Afr. J. Agric. Res. 2011, 6, 3167-3175.

21. Franzen, D. Fertilizing Flax in North Dakota; Extension Service SF-717; North Dakota Agricultural Experimental Station: Fargo, ND, USA, 2017. Available online: https://www.ag.ndsu.edu/publications/crops/fertilizing-flax (accessed on 24 August 2021).

22. Hocking, P.J.; Kirkegaard, J.A.; Angus, J.F.; Gibson, A.H.; Koetz, E.A. Comparison of canola, Indian mustard and Linola in two contrasting environments. I. Effects of nitrogen fertilizer on dry-matter production, seed yield and seed quality. Field Crop. Res. 1997, 49, 107-125. [CrossRef]

23. Ye, Q.; Zhang, H.; Wei, H.; Zhang, Y.; Wang, B.; Xia, K.; Huo, Z.; Dai, Q.; Xu, K. Effects of nitrogen fertilizer on nitrogen use efficiency and yield of rice under different soil conditions. Front. Agric. China 2007, 1, 30-36. [CrossRef]

24. Goulding, K.; Jarvis, S.; Whitmore, A. Optimizing nutrient management for farm systems. Philos. Trans. R. Soc. Lond. B Biol. Sci. 2008, 363, 667-680. [CrossRef] [PubMed]

25. Folina, A.; Tataridas, A.; Mavroeidis, A.; Kousta, A.; Katsenios, N.; Efthimiadou, A.; Travlos, I.; Roussis, I.; Darawsheh, M.K.; Papastylianou, P.; et al. Evaluation of various nitrogen indices in $\mathrm{N}$-fertilizers with inhibitors in field crops: A review. Agronomy 2021, 11, 418. [CrossRef] 
26. Hassan, Q.K.; Bourque, C.P.; Meng, F.R.; Richards, W. Spatial mapping of growing degree days: An application of MODIS-based surface temperatures and enhanced vegetation index. J. Appl. Remote Sens. 2007, 1, 013511. [CrossRef]

27. Cleland, E.E.; Chuine, I.; Menzel, A.; Mooney, H.A.; Schwartz, M.D. Shifting plant phenology in response to global change. Trends Ecol. Evol. 2007, 22, 357-365. [CrossRef]

28. Swan, J.B.; Schneider, E.C.; Moncrief, J.F.; Paulson, W.H.; Peterson, A.E. Estimating corn growth, yield, and grain moisture from air growing degree days and residue Cover. Agron. J. 1987, 79, 53-60. [CrossRef]

29. Liu, Y.; Su, L.; Wang, Q.; Zhang, J.; Shan, Y.; Deng, M. Comprehensive and quantitative analysis of growth characteristics of winter wheat in China based on growing degree days. Adv. Agron. 2020, 159, 237-273.

30. Goudenhooft, C.; Bourmaud, A.; Baley, C. Flax (Linum usitatissimum L.) fibers for composite reinforcement: Exploring the link between plant growth, cell walls development, and fiber properties. Front. Plant Sci. 2019, 10, 411. [CrossRef] [PubMed]

31. Tiver, N.S.; Williams, R.P. Studies of the flax plant. The effect of artificial drought on growth and oil production in ani seed variety. Aust. J. Exp. Biol. Med. Sci. 1943, 21, 201-209. [CrossRef]

32. Camoglu, G.; Kaya, U.; Akkuzu, E.; Genc, L.; Gurbuz, M.; Mengu, G.P.; Kizil, U. Prediction of leaf water status using spectral indices for young olive trees. Fresenius Environ. Bull. 2013, 22, 2713-2720.

33. Lefeuvre, A.; Bourmaud, A.; Morvan, C.; Baley, C. Tensile properties of elementary fibres of flax and glass: Analysis of reproducibility and scattering. Mater. Lett. 2014, 130, 289-291. [CrossRef]

34. Du, G.H.; Liu, F.H.; Rowland, G. Fiber cell development and fiber yield of flax (Linum usitatissimum L.) affected by the seasonal temperature pattern. Can. J. Plant Sci. 2015, 95, 1215-1220. [CrossRef]

35. Bourmaud, A.; Gibaud, M.; Baley, C. Impact of the seeding rate on flax stem stability and the mechanical properties of elementary fibres. Ind. Crop. Prod. 2016, 80, 17-25. [CrossRef]

36. Mirshekari, M.; Amiri, R.; Nezhad, H.I.; Noori, S.S.; Zandvakili, O.R. Effects of planting date and water deficit on quantitative and qualitative traits of flax seed. AEJAES 2012, 12, 901-913. [CrossRef]

37. Ali, S.; Cheema, M.A.; Wahid, M.A.; Sattar, A.; Saleem, M.F. Comparative production potential of linola and linseed under different nitrogen levels. Crop Environ. 2011, 2, 33-36.

38. Kariuki, L.W.; Masinde, P.W.; Onyango, A.N.; Githiri, S.M.; Ogila, K. The growth and seed yield of five linseed (Linum usitatissimum L.) varieties as influenced by nitrogen application. J. Anim. Plant Sci. 2014, 22, 3493-3509.

39. Soethe, G.; Feiden, A.; Bassegio, D.; Santos, R.F.; de Souza, S.N.M.; Secco, D. Sources and rates of nitrogen in the cultivation of flax. Afr. J. Agric. Res. 2013, 8, 2249-2253. [CrossRef]

40. Leghari, S.J.; Wahocho, N.A.; Laghari, G.M.; HafeezLaghari, A.; MustafaBhabhan, G.; Hussain-Talpur, K.; Bhutto, T.A.; Wahocho, S.A.; Lashari, A.A. Role of nitrogen for plant growth and development: A review. Adv. Environ. Biol. 2016, 10, $209-219$.

41. Evans, J.R. Photosynthesis and nitrogen relationships in leaves of C3 plants. Oecologia 1989, 78, 9-19. [CrossRef]

42. Warren, C.R.; Adams, M.A. Phosphorus affects growth and partitioning of nitrogen to Rubisco in Pinus pinaster. Tree Physiol. 2002, 22, 11-19. [CrossRef]

43. Takashima, T.; Hikosaka, K.; Hirose, T. Photosynthesis or persistence: Nitrogen allocation in leaves of evergreen and deciduous Quercus species. Plant Cell Environ. 2004, 27, 1047-1054. [CrossRef]

44. Yu, F.; Li, Y.; Li, F.; Zhou, Z.; Chen, C.; Liang, X.; Li, C.; Liu, K. Nitrogen fertilizers promote plant growth and assist in manganese (Mn) accumulation by Polygonum pubescens Blume cultured in Mn tailings soil. Int. J. Phytoremediat. 2019, 21, 1225-1233. [CrossRef] [PubMed]

45. Wu, L.H.; Li, H.; Luo, Y.M.; Christie, P. Nutrients can enhance phytoremediation of copper-polluted soil by Indian mustard. Environ. Geochem. Health 2004, 26, 331-335. [CrossRef]

46. Yu, F.; Liu, K.; Li, M.; Zhou, Z.; Deng, H.; Chen, B. Effects of cadmium on enzymatic and non-enzymatic antioxidative defenses of rice (Oryza sativa L.). Int. J. Phytoremediat. 2013, 15, 513-521. [CrossRef] [PubMed]

47. Maleva, M.; Borisova, G.; Chukina, N.; Kumar, A. Urea increased nickel and copper accumulation in the leaves of Egeria densa (Planch.) Casp. and Ceratophyllum demersum L. during short-term exposure. Ecotoxicol. Environ. Saf. 2018, 148, 152-159. [CrossRef] [PubMed]

48. Racz, G.J.; Webber, M.D.; Soper, R.J.; Hedlin, R.A. Phosphorus and nitrogen utilization by rape, flax, and wheat. Agron. J. 1965, 57, 335-337. [CrossRef]

49. Diepenbrock, W.; Iwersen, D. Yield development in linseed (Linum usitatissimum L.). Plant Res. Dev. 1989, 30, 104-125.

50. Vallduví, G.E.S.; Flores, C.C. Fertilización nitrogenada en el cultivo de lino oleaginoso (Linum usitatissimum L.). Efecto sobre el rendimiento y sus componentes. Investigación agraria. Prod. Protección Veg. 1999, 14, 475-482.

51. Chaudhary, S. Response of promising linseed varieties to nitrogen. Asian J. Biol. Sci. 2010, 4, $210-211$.

52. Yang, J.; Zhang, J. Grain filling of cereals under soil drying. New Phytol. 2006, 169, 223-236. [CrossRef]

53. Naqvi, P.A.; Rai, M.; Vasishtha, A.K. Association of different components of seed and oil in linseed. Indian J. Agric. Sci. 1987, 57, 231-236.

54. Bajpai, M.; Pandey, S.; Vasishtha, A.K. Spectrum of variability of characteristics and composition of the oils from different genetic varieties of linseed. J. Am. Oil Chem. Soc. 1985, 62, 628.

55. Dybing, C.D. Influence of nitrogen level on flax growth and oil production in varied environments. Crop Sci. 1964, 4, 491-494. [CrossRef] 
56. Hocking, P.J. Effect of nitrogen supply on the growth, yield components and distribution of nitrogen in linola. J. Plant Nutr. 1995, 18, 257-275. [CrossRef]

57. Hocking, P.J.; Pinkerton, A. Response of growth and yield components of linseed to the onset or relief of nitrogen stress at several stages of crop development. Field Crop. Res. 1991, 27, 83-102. [CrossRef]

58. Rodgers, G.A. Nitrification inhibitors in agriculture. J. Environ. Sci. Health Part A 1986, 21, 701-722. [CrossRef]

59. Artola, E.; Cruchaga, S.; Ariz, I.; Moran, J.F.; Garnica, M.; Houdusse, F.; Garcia-Mina, J.M.; Irigoyen, I.; Lasa, B.; Aparicio-Tejo, P.M. Effect of $\mathrm{N}$-(N-butyl) thiophosphoric triamide on urea metabolism and the assimilation of ammonium by Triticum aestivum $\mathrm{L}$. Plant Growth Regul. 2011, 63, 73-79. [CrossRef]

60. Savci, S. Investigation of effect of chemical fertilizers on environment. APCBEE Procedia 2012, 1, 287-292. [CrossRef]

61. Khan, M.N.; Mohammad, F. Eutrophication: Challenges and solutions. In Eutrophication: Causes, Consequences and Control; Ansari, A.A., Gill, S.S., Eds.; Springer: Dordrecht, The Netherlands, 2014; pp. 1-15. [CrossRef]

62. Lassaletta, L.; Billen, G.; Grizzetti, B.; Anglade, J.; Garnier, J. 50 year trends in nitrogen use efficiency of world cropping systems: The relationship between yield and nitrogen input to cropland. Environ. Res. Lett. 2014, 9, 9-18. [CrossRef]

63. Kakabouki, I.; Karydogianni, S.; Zisi, C.; Folina, A. Effect of fertilization with $N$-inhibitors on root and crop development of flaxseed crop (Linum usitatissimum L.). AJAS 2020, 42, 411-424. [CrossRef]

64. del Pozo, A.; Brunel-Saldias, N.; Engler, A.; Ortega-Farias, S.; Acevedo-Opazo, C.; Lobos, G.A.; Jara-Rojas, R.; Molina-Montenegro, M.A. Climate change impacts and adaptation strategies of agriculture in Mediterranean-Climate Regions (MCRs). Sustainability 2019, 11, 2769. [CrossRef]

65. Raza, A.; Razzaq, A.; Mehmood, S.S.; Zou, X.; Zhang, X.; Lv, Y.; Xu, J. Impact of climate change on crops adaptation and strategies to tackle its outcome: A review. Plants 2019, 8, 34. [CrossRef]

66. Kraft, J.M.; Kommedahl, T.; Linck, A.J. Histological study of malformation in flax seed after exposure to $31^{\circ} \mathrm{C}$. Bot. Gaz. 1963, 124 , 367-371. [CrossRef]

67. Gusta, L.V.; O'Connor, B.J.; Bhatty, R.S. Flax (Linum usitatissimum L.) responses to chilling and heat stress on flowering and seed yield. Can. J. Plant Sci. 1997, 77, 97-99. [CrossRef]

68. Jensen, P.K.; Permin, O. Tolerance of flax to pre-and post-emergence herbicides. Tidsskr. Planteavl. 1992, 96, 57-62.

69. Nalewaja, J.D.; Bothun, R.E. Response of flax to postemergence herbicides. Crop Sci. 1969, 9, 160-162. [CrossRef]

70. Nalewaja, J.D. Reaction of flax to dicamba applied at several stages. Weed Sci. 1969, 17, 385-387. [CrossRef]

71. Lafond, G.; Grant, C.; Johnston, A.; McAndrew, D.; May, W. Management of nitrogen and phosphorus fertilizer in no-till flax. Can. J. Plant Sci. 2003, 83, 681-688. [CrossRef]

72. Bremner, J.M. Determination of nitrogen in soil by Kjedahl method. J. Agric. Sci. 1960, 55, 11-33. [CrossRef] 